\title{
TRTaKadeмi
}

ISSN 2149-9446 | Cilt 07 | Sayı 14 | Ocak 2022 | Sosyal Medya

\section{Tık Odaklı Başlıklar ve Okuyucu Refleksleri Üzerine Bir Araştırma: Odak Grup Çalışması}

\author{
Zeynep Burcu ŞAHIN* \\ Yıldız BíRINCIOĞLU**
}

\begin{abstract}
Öz
Haberciliğin dijitalleşmesiyle birlikte karşılaşılan etik sorunların birçoğu, ekonomik temelli olarak karşımıza çıkmaktadır. Bunlardan biri olan tık odaklı başıkların ve tık odaklı haberciliğin özünde çoğunlukla okuyucuyu yanlış yönlendirme ya da yanlış bilgilendirme amacı yoktur. Temel amaç, okuyucunun ilgisini çekerek haberin yer aldığı sayfanın görüntülenme sayısını ve söz konusu haber sitesinin reklam gelirlerini arttırmaktır. Bu yapısıyla profesyonel haberciliğin temel işleyişi ve işleviyle çelişen tık odaklı anlayış; yanıltıcı başlık, görsel ve/veya yanıltıcı içerikle karşımıza çıkabilmektedir. Bu çalışmada günümüzde oldukça yaygınlaşan ve sadece magazin haberlerinde değil ekonomik, siyasi haberlerde de karşımıza çıkan tık odaklı başıkların ve haberlerin habercilik anlayışı üzerindeki olumlu/olumsuz etkilerinin incelenmesi amaçlanmıştır. Çalışmanın amacı; farklı yazarlar tarafindan "ttk kapanı", "çöp haber", "kapan manşetler" olarak adlandırılan ve içerik, başlık ve görsel arasındaki uyumun bilinçli bir biçimde manipüle edildiği haber içeriklerine ilişkin kullanıcı farkındalığını ve reflekslerini tespit etmektir. Çalışma, odak grup yöntemi esas alınarak gerçekleştirilmiştir. Çalışmada; kullanıııların yanıltııı başlık ve görsel kullanımına yer verildiği, haber içeriğinde gereksiz tekrarların kullanıldığı, haber dilinin uzun ve ağdalı bir dil üzerinden inşa edildiği, haberlerin çoğunda başlık ve içerik ilişkisinin uyumsuzluk taşıdığına ilişkin refleksler geliştirdiği sonucuna ulaşılmıştır.
\end{abstract}

Anahtar Kelimeler: Tık Odaklı Habercilik, Tabloidleşme, Tık Yemi, Kapan Manşetler, Odak Grup

*Dr. Öğr. Üyesi, İstanbul Gelişim Üniversitesi Uygulamalı Bilimler Fakültesi Halkla illişkiler ve Reklamclık, zbsahin@gelisim.edu.tr

**Doç. Dr., Üsküdar Üniversitesi Illetişim Fakültesi Yeni Medya ve İletişim Bölümü, derya.birincioglu@uskudar.edu.tr

Şahin, Z. B. \& Birincioğlu, Y. (2022). Tık Odaklı Başlıklar ve Okuyucu Refleksleri Üzerine Bir Araştırma: Odak Grup Çalışması. TRT Akademi, 7 (14) , 236-261. DOI: 10.37679/trta.1013651

\section{Araştırma Makalesi}

Geliş Tarihi: 22.10.2021

Revizyon Tarihi: 27.11.2021

Kabul Tarihi: 14.01.2022

ORCID ID: 0000-0003-1870-3073 ORCID ID: 0000-0003-0119-9341 DOI: 10.37679/trta.1013651 


\title{
TRTakadeмi
}

ISSN 2149-9446 | Volume 07 | Issue 14 | January 2022 | Social Media

\section{A Study on Click-Focused Headlines and Reader Reflexes: Focus Group}

\section{Zeynep Burcu ŞAHIN Yıldız BíRincioĞLU}

\begin{abstract}
Many of the ethical problems encountered with the digitalization of journalism appear to be economically based. One of these, click-bait headlines and click-bait journalism are mostly not intended to mislead or misinform the reader. The main purpose of click-bait is to increase the number of views and the advertising revenues by attracting the attention of the reader. This click-oriented approach, which contradicts the basic operation and function of professional journalism; may appear with a misleading title, visual and/or misleading content. This study is aimed to examine the positive/negative effects of click-bait headlines and news, which are quite common today and not only in tabloid, but also in economic and political news, on the understanding of journalism. The study aims to determine the awareness and reflexes of the users about the news content, which is called "click-bait", "garbage news", "snatching headlines" by different authors, and in which the harmony between content, title, and visual is consciously manipulated. The study was carried out based on the focus group method.
\end{abstract}

Keywords: Clickbait Journalism, Tabloidization, Clickbait, Digital Journalism, Focus Group 


\section{Giriş}

Haberin ve haberciliğin dijital alana taşınması, sağladığı teknolojik olanaklarla gazetecilik mesleğinin dönüşmesini ve gelişmesini sağlayabilecek geniş bir alan yaratmıştır. Diğer yandan söz konusu alanın ve teknolojik imkânların gazetecilik mesleği dışında kalan ve salt ticari kaygıyla hareket eden kişi ve kişilerce de rahatIıkla kullanılabilir olması (Çelik, 2020, s. 17), haberciliğin tartışmalı ve kaygan bir zeminde yer almasına neden olmaktadır. Bununla birlikte, kullanıcıların beklentilerini karşılayacak profesyonel haberciliğe ihtiyaç artmaktadır. Nitekim Oxford Üniversitesi Reuters Gazetecilik Çalışmaları Enstitüsü'nün 2020 Dijital Haber Raporu'na göre küresel koronavirüs krizi, habere ve haberciliğe olan bakışta görece değişiklikler yaratmıştır (Reuters Digital Report 2020). Rapora göre; Türkiye'de haberlere duyulan genel güven seviyesi \%9 artarak \%55’e yükselmiştir. Sosyal medyadan gelen haberlere güven ise \%51'dir. Dünya geneline bakıldığında, internette haber tüketimi konusunda neyin gerçek neyin yalan olduğuna ilişkin kaygı seviyesi ise \%56 olarak görülmektedir. Bir diğer deyişle, kullanıcıların \%56'sı internette tükettikleri haberin doğru olup olmadığı hususunda şüphe ve kaygı taşımakta ancak yine de haber alma ihtiyacını karşılamak için çeşitli haber sitelerine ve sosyal medya platformlarına yönlenmektedirler (Reuters Digital Report 2020). Kullanıcıların güvensizliğinin altında ekonomik, politik, sosyolojik ve psikolojik birçok etkenin olması mümkündür. Teknolojik gelişmelerle birlikte artan manipülasyon ve suistimal araçları/yöntemleri ise bu etkenlerden sadece birini oluşturmaktadır. Bununla birlikte, dijitalleşmenin ve yeni teknolojik imkânların haberciliğin temel unsurlarında ve yapısında çeşitli değişiklikleri gerektirmesi de beklenen bir durumdur. Haberlerin modern bir sunumuna olanak sağlayan dijital habercilik, medyanın ifade tarzına özgünlük katmakta ve haberi internetin teknolojik ve etkileyici araçlarına uyarlamaktadır (Beleslin, 2017, s. 364). Bu çalışma, habere olan güvensizliğin altındaki nedenlerden sadece biri olarak görülen tık odaklı başlıklara, tık odaklı habercilik anlayışına ve söz konusu kavramların haberin unsurlarında yarattğı/yaratabileceği/yaratması gereken değişikliklere odaklanmaktadır. Diğer yandan, çalışmada tık odaklı başlıklar ve tık odaklı habercilik, iki farklı kavrama işaret etmek üzere kullanılmıştır.

Dijitalleşme ve özellikle sosyal medyanın aktif kullanımı ile bilgi akışında sınırsız rekabetle karşılaşan meslek mensuplarının geleneksel rating/tiraj kaygısı, yerini "tık" ve "sayfa görüntülenme" kaygısına bırakmaktadır. Nitekim Lee vd., (2014) araştırmalarında kullanıcıların tık eğilimlerinin editoryal kararlar üzerine etkisini bulgulamıştır. Bu noktada tık odaklı başlıklar ve tık odaklı habercilik özünde ticari 
kaygı taşıyan bir habercilik anlayışı olarak karşımıza çıkmaktadır (Karaca, 2019, s. 12). Reklam gelirlerini odak alan bu anlayışta haberin ve haberciliğin kamusal yararı büyük ölçüde göz ardı edilmektedir (Beleslin, 2017, s. 365). Diğer yandan ekonomik sebepleri üzerinde durduğumuz bu habercilik anlayışı hem sosyal hem de ekonomik açıdan gerçek sonuçlar doğurabilmektedir (Chen vd., 2015, s. 15). Örneğin, 2008 yılında Apple CEO'su Steve Jobs'un ciddi bir kalp krizi geçirdiğini iddia eden yalan haberler, şirketin hisse senedi fiyatının \%10 düşmesine neden olmuştur (Sandoval, 2008'den akt. Chen vd., 2015, s. 15). Bununla birlikte olası sonuçlar sadece ekonomik kazanç ya da kayıplar ile sınırlı değildir. Yanıltıcı başlıklar ve haberler arasında doğru ve tarafsız habere ulaşımın zorlaşt̆ğı ve güvenin sarsıldığı bir durumda, demokrasinin de tehlikeye girebileceği göz önünde bulundurulmalıdır.

Tık odağı, literatürde tık yemi, tık kapanı, tık odaklı başlık, tık odaklı habercilik gibi farklı kavramlarla karşılanmaktadır. Bu çalışma, tık odağını iki farklı başlık ve anlayış çerçevesinde incelemeyi amaçlamaktadır. Tık odaklı başlıklar, kullanıcının dikkatini çekmek ve tıklama refleksini oluşturmak amacıyla kurgulanmış; dikkat çekici, merak uyandıran ya da sansasyonel ifadeler için tasarlanmaktadır. Tıklanan haber içeriğinin gerçeği yansıtması ve/veya kullanıcının beklentileriyle uyumlu olması ise farklı bir husustur. Başlık ve içeriğin uyumsuz olduğu, gerçek dışı bilgilerin paylaşıldığı, beklentinin tatmin olmadığı durumlar ise tık odaklı habercilik anlayışına işaret etmektedir. Birinci durumda, haber başlıklarının kullanıcıların beklentileri doğrultusunda oluşturulması hedeflenirken ikinci durum, ticari amaçlı ve kullanıcıyı aldatmaya yönelik etik bir soruna işaret etmektedir.

Tık odaklı başlıkların ve tık odaklı haberciliğin kamunun medyadan reel beklentisiyle de alakası olduğu düşünülebilir. Nitekim okuyucuların haber başlığının kurallara uygun bir biçimde verildiği haberi tıklamayı ve paylaşmayı tercih etmediği; sansasyonel bir başlık tercih edildiğinde ise aynı içeriğin tıklanma ve paylaşılma sayısının yüksek oranda arttı̆ı görülmektedir (Reis vd., 2015). Bu durumu, haber platformunun tkklanma ve kar beklentisiyle açıklamak mümkün olduğu gibi profesyonel ya da amatör bir habercinin oluşturduğu içeriğin daha fazla kişi tarafindan okunması isteği ile de açıklamak mümkündür. Bir diğer deyişle, tık odaklı başlıklar, profesyonelce hazırlanmış bir haber içeriğinin okuyucunun dikkatini çekerek görüntülenmesini arttırmak amacıyla kullanılabildiği gibi; kullanıcıyı, başlık ve içerik arasında uyumsuzluk olan ve/veya içerik itibariyle doyurucu olmayan haber içeriklerine çekmek amacıyla da kullanılabilmektedir. Birinci durum, haberin unsurlarında ve habercilik pratiklerindeki kullanıc beklentileri ve talepleri 
doğrultusunda yapılan değişikliklere işaret ederken ikinci durum profesyonellikten uzak ticari kaygıları göstermektedir. Bu durum da bizleri haberin tarihi boyunca tartışılan tabloidleşme olgusuna geri döndürmektedir.

Magazin konuları ile haber ögelerinin önemini "olabildiğinden daha ilginç, sıra dışı ve abartılı" bir sunum stratejisi şeklinde ortaya koyan tabloidleştirme arasında ayrım yapmak gereklidir (Molek-Kozakowska, 2013'ten akt. Chen vd., 2015, s. 15). Genel olarak bakıldığında, haber sitelerinin editörlerle görüşme çerçevesinde hazırladıkları çalışmalarında haber konularının ve içeriklerinin okuyucu beklentilerine göre şekillendiği görülmektedir. Diğer bir ifadeyle, kullanıcıların şikâyet ettikleri tık odaklı başlıklar ve tık odaklı habercilik, bizzat kullanıcıların reflekslerinin gözlemlenmesi sonucu onların talep ve beklentileri çerçevesinde oluşturulmaktadır (Lee vd.'den akt. Özyal, 2016, s. 278). Bu noktada, eylemle söylemin uyuşmadığı görülmektedir. Bu araştırma, merkezine tam olarak var olan bu uyuşmazlığı almaktadır. Çalışmanın konusunu, katılımcıların tık odaklı habercilik anlayışına ilişkin düşünceleri, farkındalıkları, refleksleri ve eğilimlerini oluşturmaktadır. Araştırmanın amacı, katılımcıların tık odaklı başlıklara ve haberciliğe ilişkin düşüncelerinin, reflekslerinin ve eğilimlerinin belirlenmesidir. Bu doğrultuda odak grup çalışması çerçevesinde ifade ettikleri düşünceleri yanında fiili olarak eylemleri, tercihleri ve tık odaklı haberlere ilişkin tepkileri gözlemlenerek bu iki veri seti arasındaki olası paralellik ya da tutarsızlıklar saptanmaya çalışılmıştır.

Çalışmanın problematiğini oluşturan şu sorulara cevap aramaktadır; Kullanıcılar tık odaklı haber okuduklarının farkındalar mıdır? Bu başlıkların tercih edilme nedenini fark ediyorlar mı? Bu tık odaklı habercilik içeren başlıkların tercih edilme ve okunma sıklıkları nedir? Temelde bu sorulara cevap bulmak amacıyla odak grup görüşmesi bağlamında araştırmada 7 katılımcı ile çevrim içi görüşmeler gerçekleştirilmiştir.

Odak grup görüşmelerinde katılımcılar, görüşlerini diğer katılımcıların varlığında ve onların ifadelerini göz önünde bulundurarak oluşturmaktadır. Bu suretle, grup içerisinde gerçek yaşamda yer alan düşüncelerin geliştirilmesine imkân sağlanır ve odak gruba toplumsallık özelliği kazandırılır (Erdoğan ve Uyan-Semerci, 2021, s. 173). Odak grup, görüşülen kişiler arasındaki etkileşimden kaynaklanan ve katıIımcıların perspektifinden biçimlendirilen bir araştırma yöntemi olması nedeniyle gerçek yaşamdaki düşünce geliştirme sürecine benzer bir pratik sunmaktadır (Erdoğan ve Uyan Semerci, 2021, s. 194). Kendi küçük grup dinamikleri ile toplumsal dinamikleri bir ölçüde taklit edebilme özelliği yaratan bu pratiğin tercih nedenlerini anlamaya dair bir yol haritası sunacağı düşünülerek çalışmada derinlemesine mülakat tekniği yerine odak grup görüşmesi tercih edilmektedir. Diğer bir deyişle, 
odak grup görüşmelerinin, katılımcı perspektif taşıması ve sponten özelliği, toplumsal konularda tartş̧maların nasıl yürütüldüğüne yönelik gözlem imkânı sunması ve karar verme süreçlerinin nasıl gerçekleştiğinin görülmesini sağlaması nedeniyle kullanılmıştır. Araştırmanın ana problematiğini oluşturan uyuşmazlığın derinlemesine değerlendirmesine geçmeden önce tk odaklı habercilik ile ilgili yapılan çalışmalara değinmek anlamlı olabilir.

\section{2. "Tık Yemi" Üzerine Literatür Taraması}

Habercilik dijitalleşme ile farklı bir boyuta taşınmış, diğer yandan insanların haber alma alışkanlıklarında köklü değişiklikler yaşanmıştır. "Gazetecilik mesleği dijitalleşme ile tıklanma hedefleri, sayfa görüntüleme sayısı, tık tuzağı, yanıltıcı başlık, banner, advertorial, arama motoru optimizasyonu gibi yeni kavramlarla ve etik sorunlarla tanışmıştır" (Korap Özel ve Deniz, 2019, s. 445). Bununla birlikte, söz konusu kavramların geleneksel medyada da karşılıklarının olduğu ve beraberinde getirdikleri etik sorunların da yeni araçlar vasıtasıyla gerçekleştirilen mevcut etik sorunlar olduğunu söylemek mümkündür. Bir diğer deyişle rating-tiraj kaygısı, yeni medya ortamında yerini sayfa görüntüleme sayısı ya da tkk kaygısına; geleneksel reklamlar ise bannerlara bırakmıştır. Amaç ise aynıdır; daha büyük kitlelere hitap edebilmek ve ticari kârı arttırmaktır.

Kalsson ve Strömback çevrim içi haberlerin iki temel özellik ile karakterize edilebileceğini ifade etmiştir; etkileşim ve dolaysızlık (Akt. Reis vd., 2015). Etkileşim, insanların yalnızca ilgilendikleri haberleri kullanma eğiliminde olmaları ile ilgilidir; dolaysızlık ise insanların neredeyse hiç gecikmeden en son haberler hakkında bilgilendirilmeyi beklediğini belirtir.

Haberin üretimi ve dağıtımı, çevrim içi habercilikte bir dönüşümü beraberinde getirmekte ve bu durum habercilerin yetkinlik ve dijital beceriler haricinde yaratcılık ve sürekli yenilenme gerektiren sürekli ve yenilenen zorluklarla mücadelesini zorunlu kılmaktadır (García vd., 2017, s. 262).

Çelik (2020), dijital haberciliği tık odaklı haberciliğe götüren süreçte arama motoru otomasyonunun önemine işaret eder. Mühendislikle haberciliğin kesişiminde yer alan arama motoru optimizasyonu basitçe arama motorlarında, "En çok aranan kelimelere ve cümlelere odaklanarak haber yazma, daha fazla tık dolayısıyla daha fazla reklam alma amaçlarıyla Google aramalarında üst sıralarda çıkmak için haberleri güncelleme, değiştirme, ilgi çekici kılma stratejilerini içeren bir uzmanlık alanıdır" (Çelik, 2020, s. 17). Bu doğrultuda tık odaklı haberciliğin gazetecilik pratiğinin dışına çıkan unsurlar barındırdığı ve kamu yararından ziyade ekonomik amaçlara odaklandığı ifade edilebilir. 
Diğer yandan geleneksel haberciliğin fiziksel sınırlarını kaldıran dijital haberciliğin rekabete açık yapısıyla tık odaklı haberciliği teşvik ettiği de öne sürülebilir (Reis, 2015). Nitekim hızı tüketimin ön planda olduğu bu yeni dönemde dijital habercilik aktörleri kullanıcıların dikkatini çekecek başlık ve haberlere odaklanmaktadırlar. Dijital haberciliğin temel gelir kaynaklarından olan reklam gelirlerinin tık odaklı belirlenmesi de bu hususta itici bir güç oluşturabilmektedir. Bir diğer deyişle haberin reklama olan bağımlılığı yeni haber pratiklerini okumada göz ardı edilmemesi gereken bir husustur (Özyal, 2016, s. 282).

Tık odaklı başlıklar, kullanıcıların haber alma alışkanlıklarında meydana gelen değişikliklere paralel biçimde, söz konusu haber içeriklerinin görüntülenme sayılarını arttırmak amacıyla kurgulanmış haber başlıklarından oluşmaktadır. Dönmez, bu değişimi şu şekilde açıklamaktadır: "Haber değeri varmış izlenimi uyandıran ve yakınlık, korku, endişe, merak, heyecan uyandıracak bir dille oluşturulan bu haber başlıklarına yüklenen rol, cursor (imleç) tam da başlığın üstüne denk gelecek biçimde, okurun mouseu (fareyi) tıklatmasını sağlamaktır" (2010, s. 105). Aynı zamanda tık odaklı başlık, "Tıklanma sayısını arttırmak için oluşturulan haber başlıklarını ve ona eşlik eden görselleri ifade eden tık odaklı haber sunumları, okurlara haber en basit ve en doğru biçimde nasıl ulaştırabilir sorusu yerine, mevcut materyal ile en fazla tık nasıl alınır sorusuna cevap arayan içerik yönetimli biçimsel bir habercilik pratiğidir" (Özyal, 2016, s. 280).

"Tık tuzağını online gazetecilikte tabloidleşmenin yeni bir formu olarak gören Chen vd.'ne göre ise tık tuzağının temel amacı dikkat çekmek ve kullanıcıları o linke tıklamaya cesaretlendirmek olan içerik olarak tanımlanmaktadır (2015'ten akt. Korap Özel ve Deniz, 2019, s. 449). Tabloidleşme fikir gazetelerinin (prestige press) ya da yazılarının alternatifi olarak kısa zamanda okunup tüketilmeleri, resimler ve çarpıcı başlıklarla haberlerin sunulması nedeniyle oluşturulmuştur. Fischer (2014) tabloid gazeteciliği, geleneksel gazeteciliğin nesnellik ve hesap verilebilirlik ideallerinin hakikat arayışı tarafindan yönlendirilen antitezi olarak tanımlar. Bir dizi haber değeri- ünlü olma öyküleri, çarpıcı felaket haberleri, bireysel suç öyküleri- tabloid habercilikle birlikte yaygınlaşmış ve neredeyse tüm dünyada kabul görmüştür. Tabloid format olarak isimlendirilebilecek olan bu formatların temel özelliği olayları haberleştirirken, okuyucunun ilgisini çekecek ve merak uyandıracak yönlerini öne çıkartarak, "olayları" seyirlik bir anlatıya dönüştürmeleridir. Bu seyirlik öyküler, çoğunlukla günümüzde sokaktaki insanın başına gelen "felaketler" gittikçe daha fazla tabloid formatların konusunu oluşturmaktadır (TESEV, 2012, s. 55). Tabloid basınla ortaya çıkan anlat biçimi, günümüzde egemen anlat biçimine dönüşmüştür. Bu anlat biçimi, okuyucunun haber 
sitesinden beklediklerini, okuma ve anlamlandırma süreçlerini de büyük ölçüde biçimlendirmektedir. Tabloidleşmeyi az metin, siyasi haber, uluslararası haber ve daha çok görüntü eğlence ve insani ilgi haberi olarak ifade etmek mümkündür. Medya araçlarında tabloidleşme kavramı çerçevesinde görsel unsurlar ve merak duygusunu kışkırtan habercilik anlayışı ile dramatik etkiyi arttıracak ses ve müzik efektlerinin abartılı olarak kullanıldığı, özellikle habercilik alanında sürekli tekrar eden spot ve sloganlaştırılmış açıklamalar ile haberin klipleştirilerek ya da foto galerileştirilerek okuyucunun/izler kitlenin dikkatinin sömürülmesi amacı taşıdığı belirtilebilir.

Tabloidleşme konusuna dair farklı görüşler bulunur. Bir grup görüş tabloid medyayı kamusal meselelerin geleneksel medyada evrenselleştirici, kişisel olmayan bir şekilde temsil edilmesini düzeltecek bir potansiyel olarak görür. Onlara göre, tabloid medya tarihsel olarak medya temsilinde sesleri ve deneyimleri yok sayılan toplumsal grupların bütünleştirilmesi aracılığıyla resmi medyadan daha içerici, katılımcı ve demokratik olabilir. Ancak medya da temsil olanağı sağladığı bu sesleri, malzeme olarak sansasyonel bir biçimde kullanarak sömürebilmektedir. İkincisi, tabloidleşmeyi eleştirerek onun demokrasi için tehlikelerine işaret eden görüştür (Çaplı, 2002, s. 91). Türkiye'de medyanın tabloidleşme kavramıyla tanışması 1980'lere denk gelir. Doğrudan temsil kısıtlaması yaşayan gruplarının kendileri ifade etme yöntemi olarak da işlerlik kazanmaz. Daha çok medya patronlarının gazeteyi araç olarak kullanması ve daha çok satmak, dikkat çekmek için başvurdukları yöntemlerden biri olarak karşımıza çıkar. Yıllar içinde medya sektörünün ticarileşmesiyle farklı şekillere dönüşür: Sansasyonel başlıklar, dramatik içerik yazıları ve magazinleşme olguları, haber programlarından medyanın birbirinden farklı her türlü aracına taşınır. Bir bakıma, tabloidleşme bilgi programlarına eğlencenin eklenmesi boyutuyla bil-eğlencenin ileri bir biçimidir. Hâkim güçlerin resmî gazetecilik anlayışından farklı olarak tabloid gazeteciliğin hâkim anlayışları eleştirerek bunları altüst edebileceğini, hatta resmî ve hâkim olana alternatif bir gerçeklik kurarak özgürleşme sağlayacağı düşünülmektedir (Bek, 2004). Siyaset haberlerine ilgisi olmayan okuyucunun/izler kitlenin popülerleşen siyasetle yeniden hedef kitle potasına çekileceği düşünülür. Bunun yanı sıra insanların sorunlardan kaçıp rahatlamasını ve eğlenmesini sağladığı yönünde bir kanaatin oluşmasına neden olmaktadır. Tabloid haberciliğin öne çıkardığı olumsuz olayların hep bir haber değerine sahip olduğu düşünülmektedir (Çaplı, 2002, s. 92). Tabloid formatlar eğlenmek, hoşça vakit geçirmek, başına kötü şeyler ve bireysel felaketler gelenlere acıyarak üzülerek bakmak içindir. Bununla birlikte tabloidleşme nedeniyle bireyler yabancılaşıp politik olarak uyku durumuna geçebilmektedir. 
Bu noktada ötekilerin yaşamını izleyerek yargılamak, onların yaşamı hakkında sorumluluk almaktan ya da taşımaktan daha az rahatsız edici olmaktadır. Günümüzde ise tabloid habercilik ve tabloidleşmenin içine sızdığı dijitalleşme, günlük yaşamın, günlük iletişimin üzerine kurulu olduğu haber değerlerini kullanmaktadır.

Dijital haberciliğin beraberinde getirdiği artan rekabet oranı haber başlıklarının daha agresif, abartılı ve hatta yanlış yönlendiren bir yapıya sahip olmasına neden olmuştur (Reis vd., 2015). Dijital haberciliğin reklama ve tıka olan bağımIılığının haberciliği olumsuz anlamda dönüştürdüğü yapılan çalışmalarla ortaya konulmaya çalışılmaktadır. Tık odaklı başlıklar ve tık odaklı habercilik anlayışı ise tabloidleşme ile dijitalleşmenin kesiştiği yerde bir yandan habercilik anlayışında keskin bir değişimi simgelerken diğer yandan önemli sosyal ve ekonomik sonuçlar doğuran/doğurabilecek bir manipülasyon ve sömürü alanı olarak karşımıza çıkmaktadır. Diğer yandan haberlerin tabloidleştirilmesi ve dijital içeriğe geçiş, haber tuzağı kullanımını teşvik etmektedir (Chen vd., 2015, s. 18). Bununla birlikte sansasyonel habercilikle tık odaklı habercilik arasında belirgin farklar da vardır. Nitekim Çelik'e göre, "Sansasyonel bir olayı yakalamak veya sıradan bir olayı sansasyonelleştirmek tık odaklı haberciliğe göre daha fazla gazetecilik pratiği barındırır. Tık odaklı habercilikte ise ele alınacak olan konu, önemli veya güncel olsun ya da olmasın, oluşturulan biçimsel pratikler ekseninde günün en çok okunan haberi hâline getirilebilir. Üstelik haber sunumu yayına girdiği andan itibaren izlenebilir, diğer içeriklerle karşılaştırılabilir" (Çelik, 2020, s. 17).

Zhou, tık yeminin olumsuz özelliklerini üç başlık altında değerlendirmektedir (akt. Kalender, 2019, s. 10). Birincisi; tık yemi, kullanıcıların vaktini boşa harcamaktadır. İkinci olarak gazetecilik mesleğinin itibarı zedelenir ve haber kuruluşuna duyulan güven azalır. Üçüncü olarak ise habercilikle bağdaşmayan kalitesiz içeriklerin yaygınlaşmasına neden olur.

\subsection{Tık Odaklı Haberciliğin Kullanıcılar Üzerine Etkisi}

Psikolog Lowenstein, tık odaklı başlıkların kullanıc üzerindeki etkisini merak olgusuyla bağdaştırmaktadır. Lowenstein'a göre eksik bilgi, merak ve yoksunluk etkisi yaratmakta; kullanıcıyı içeriğe tıklamaya teşvik etmektedir. Tık odaklı başııklar da kullanıcılarda bu duyguları uyandıracak şekilde kurgulanmaktadır (Beleslin, Njegovan, Vukodinoviç, 2017). Diğer yandan bilişsel çalışmalar tık tuzağının dikkat dağıtıcı bir unsur olduğuna da işaret etmiştir (Chakraborty vd., 2016).

Kullanıcılar, başlıklara tıklamaya başladıkça ve sonra yeni içeriklere geçmeye devam ettikçe, bu sürekli değişimlerden kaynaklanan dikkat dağınıklığı, bilişsel aşırı 
yüklenmeye neden olarak okuyucuları daha bilgilendirici ve derinlemesine haberleri okumaktan caydırmaktadır.

Geleneksel habercilikte reyting ve tiraj olarak kendini gösteren yarış, dijital habercilikle birlikte tıklanma sayısıyla ölçümlenmeye başlanmıştır. Bununla birlikte kullanıcıların haber alma alışkanlıklarında ortaya çıkan değişiklikler de haber oluştururken bağlı kalınması beklenen temel prensiplerin yerinin kullanıcıları kayıt altına alınan tutum ve reflekslerine bırakmasına neden olmuştur (Özyal, 2016, s. 276). McDonnell bu görüşü, "Tık odaklı başlıklardan bıktıysanız yazarları suçlamayın, Facebook'ta paylaşabilecekleri güzel bir hikâye olmadığı sürece haberleri umursamayan milyonlarca genci suçlayın" sözleriyle ifade etmektedir (2016). McDonnell'a göre tık odaklı habercilik "drama içermediği sürece umursamayan" kullanıcıların yarattğı bir toplumsal sorun olarak karşımıza çıkmaktadır.

Bununla birlikte, tık odaklı haber ile tık odaklı başlıklar arasındaki farka da değinmek gerekmektedir. Nitekim kullanıcıların beklentilerindeki ve isteklerindeki değişiklikler ve okuma alışkanlıkları, habercilik anlayışında da çeşitli değişiklikleri zorunlu kılmaktadır. Bu bağlamda tık odaklı başlıklar hem haber değerini karşılayan profesyonel içerikler için hem de haber değeri taşımayan içerikler için kullanılabilmektedir. Söz konusu başlıkların farklı kullanım alanlarını okuyucunun dikkatini habere çekmek üzere tasarlanmış ve içeriğiyle beklentileri karşılayan tık odaklı başlıklar ve içerikle başıı arasında uyumun kısmen ya da tamamen göz ardı edildiği; kullanıcıyı aldatma ve oyalama amacı taşıyan tık odaklı haberler olarak açıklamak mümkündür.

Diğer yandan, haber başlıklarının taşıması gereken geleneksel özellikler de kullanıcıların beklentileri doğrultusunda geçerliliğini büyük ölçüde yitirmiş görünmektedir. Nitekim Frontiers in Psychology dergisinde 2013-2014 yılları arasında yayınlanan 2000'den fazla makalenin incelendiği bir araştırmada olumlu çerçevelemenin ve daha ilginç ifadelerin yer aldığı başlıkların çevrim içi ortamda daha fazla ilgiye yol açtığı ortaya konmuştur (https://phys.org/news/2016-08-academic-journal-articles-clickbait-y-characteristics.html, Erişim Tarihi: 26.06.2020). Diğer yandan 69907 çevrim içi haber başlığının incelendiği bir başka makalede ise aşırı ifadeler içeren başlıkların -ister olumlu ister olumsuz yönde olsun- haberin tıklanma oranını arttırdığı sonucuna ulaşılmıştır (Reis vd., 2015). Araştırmalar, haberlerin tabloidleştirilmesinin ve dijital içeriğe geçişin, haber okuyucularında ilgi uyandırmak için tıklama tuzağı kullanımını teşvik ettiğini göstermektedir (Chen vd., 2015) Tık odaklı başlıkların okuyucuyu çekmek için iyi bir yöntem olduğunu vurgulayan Berger, diğer yandan içerikte beklentisi karşılanmayan kullanıcıda haber sitesine veya haberi oluşturan kişiye karşı güvensizlik oluşturacağını ifade etmektedir 
(https://www.nytimes.com/roomfordebate/2014/11/24/you-wont-believe-what-these-people-say-about-click-bait/readers-dont-like-to-be-fooled, Erişim Tarihi: 26.06.2020). Tık odaklı başlıklar okuyucuyu çekmek için iyi bir yöntemdir. Diğer yandan kullanıc haber değeri olmayan içeriklerle vakit geçirmeyi tercih de edebilir. Ancak bu durum aynı zamanda okuyucunun habere ve haberciliğe olan güvenini sarsabilmektedir.

\section{Araştırmanın Örneklemi ve Yöntemi}

Araştırmada örneklem olarak Haziran 2021 Alexa verilerine göre en çok ziyaret edilen ikinci haber sitesi olan Hürriyet gazetesinin ana sayfasında yer alan haberler esas alınmıştır. Alexa verilerine göre tıklanma oranında ilk sırada yer alan Sözcü gazetesinin haber sitesi, söz konusu tarihte ana sayfasında yer alan tk odaklı başlıkların görece azlığı nedeniyle tercih edilmemiştir. Araştırmada yer alan katılımcıların tık odaklı haber seçimine dair düşüncelerini gözlemleyebilmek için ana sayfada yer alan haber galerisinde sayıca Sözcü gazetesinden fazla tık odaklı haber içeriği yer alan WEB sitesinin araştırmada kullanılması tercih edilmiştir.

Kovid pandemisi nedeniyle veri toplama yöntemi olarak 7 kişiyle online bir odak grup görüşmesi tasarlanmıştır. Yaklaşık 2 saat süreyi kapsayan odak grup görüşmesi 2 aşamadan oluşmuştur. İlk aşamada, odak grupta yer alan katılımcılardan 27.06.2021 tarihli Hürriyet haber sitesinin ana sayfasında yer alan 15 haber arasında gezinmeleri ve tercih ettikleri beş haberi tıklamaları istenmiştir. Başlıklar arasında gezinen ve haber seçimlerini yapan katılımcılar, tıkladıkları haberleri okuduktan sonra katılımcılara çeşitli sorular yönlendirilmiştir. İkinci aşamada ise odak grup çalışmasında bulgulanması hedeflenen sorular, grup dinamiği içerisinde katılımcılara yöneltilmiş ve cevaplamaları istenmiştir.

27 Haziran 2021 tarihli Hürriyet haber sitesinin başlıkları ve haber içerikleri analiz edilmiş; ilk 2'si hariç olmak üzere her birinin tık odaklı başlıklar kategorisinde değerlendirilebileceği görülmüştür. Söz konusu 15 haber aşağıda sıralanmıştır:

Tablo 1. 27 Haziran 2021 Tarihli Hürriyet Haber Sitesinde Yer Alan Haber Başlıkları

\begin{tabular}{|l|}
\hline 1. YKS Soru Kitapçı̆̆ı ve Cevapları Yayınlandı \\
\hline $\begin{array}{l}\text { 2. Türk Sinemasının Acı Kaybı... Usta Oyuncu Hayatını Kaybetti Cemil Rolüyle Hafızalara } \\
\text { Kazınmışt }\end{array}$ \\
\hline 3. Yeni Savaş Makinesi Göründü Sır Gibi Saklanıyordu 30 Yıl Sonra Bir İlk \\
\hline 4. Konservatuar Öğrencisi Berna'nın Ölümünde Korkunç Şüphe \\
\hline 5. Attı̆ım İmzayla Bütün Birikimlerimi Kaybettim Öğretmene Büyük Şok \\
\hline
\end{tabular}




\begin{tabular}{|l|}
\hline 6. Çok Gizli Askeri Sırlar Otobüs Durağında Bulundu \\
\hline 7. Komşunun Çığlığını Duydu, Lina’nın Feci Ölümü \\
\hline 8. Sevgilisi Paylaşınca Ortaya Çıkt. Meğer Ronaldo... \\
\hline 9. Bu Benim Hiç Hoşuma Gitmiyor Dudak Okuyabiliyorum \\
\hline 10. Koronavirüste Kötü Haber Vaka Rekoru Yasaklar Geri Geldi \\
\hline 11. Esnaflar Birbirine Girdi Park Kavgasında Kan Aktı \\
\hline 12. Baba ve Oğul 25 Yıl Arayla... Geceye İtalya Damgası! Tam 3 Kez Tarihe Geçtiler \\
\hline 13. 28 Yaşında Otizm Teşhisi Kondu 'Aniden İçimde Bir Şey Koptu’ \\
\hline 14. İki Hafta Önce Aşı Olmuştu Ünlü Şarkıcının Sır Ölümü \\
\hline 15. Insan Çocuklarını Ayırabilir mi Bir Bitmediniz \\
\hline
\end{tabular}

Krueger (1994), odak grubu önceden katılımcıların düşüncelerini serbestçe ifade edebileceği bir ortamda dikkatlice yapılandırılmış bir tartışma olarak tanımlar (Çokluk vd., 2011, s. 97). Odak gruplarda araştırmacının temel amacı, katılımcıların araştırma konusu olaya ilişkin gerçekleştirdiği tartışmalar üzerinden çıkarımlar sağlamak ve konu hakkında derin bir anlayışa sahip olmaktır (Şahin vd., 2009, s. 55). Diğer yandan amaç; "anlam çıkarmak değil anlama; genelleme değil, çeşitliliği tanımlama; katılımcılar hakkında açıklama değil, katılımcıların durumu nasıl algıladığını ortaya çıkarmaktır" (Krueger'den akt. Çokluk vd., 2011, s. 98). Aynı zamanda odak grup katılımcıların gerçek hayatta karşılaştıkları toplumsal baskıların benzerlerini yaratarak gerçek hayattaki düşünce geliştirme sürecine de daha yakın bir özellik taşımaktadır (Erdoğan ve Uyan- Semerci, 2021, s. 194). Yöntemin diğer görüşme yöntemlere nazaran en önemli avantajı grup içi etkileşimin ve grup dinamiğinin bir sonucu olarak öngörülmeyen beklenmedik bulguların ortaya çıkmasına zemin hazırlayabilmesidir. (Kitzinger, 1994, 1995). Bir diğer deyişle, odak grup çalışmasının toplumsallık, katılımcıların perspektifinden bakmayı sağlama ve toplumsal baskıların grup dinamiği içerisinde görünürlük özelliği, çalışmada bu yöntemin belirginlik kazanmasını sağlamaktadır.

Odak grup görüşmelerinin katılımcıların baskı altında hissetmediği, duygu ve düşüncelerini serbestçe ifade edebildiği koşullarda gerçekleştirilmesi önem arz etmektedir. Odak grup görüşmelerinde kathlımclların yanıt verme sürecini nasıl tamamladığı ve yanıt verenin gerçek görüşünü yansıtıp yansıtmadığı önem kazanmaktadır. Özellikle bu gruplarda görüşlerin başkalarının varlığında ve onlara yanıt olarak geliştirilmesi, toplumsal tartışmaların bir tür simülasyonunun gerçekleştirilmesi toplumsal konularda tartışmaların nasıl yürütüldüğüne, bireylerin görüşlerini nasıl oluşturduğuna, karar verme süreçlerini nasıl belirlediklerine, karşıt görüşler çerçevesinde nasıl 
bir uzlaşma ya da uzlaşmama pratiği geliştirdiklerine dair gözlem alanları sunmaktadır (Erdoğan ve Uyan Semerci, 2021, s. 195). Bu noktada grup sinerjisinin yakalanması açısından ideal bir odak grup 7-10 kişiden oluşmaktadır. Katılımcılar az sayıda belirlenen açık uçlu sorulara kendi istedikleri kadar ve kendi kelimeleri ile yanıt vermektedir. Böylelikle görüşmeyi her ne kadar araştırmacı yönlendirse de katılımcıların katkıları ile biçimlendirildiği söylenebilir. Odak grup demografik ve sosyo-ekonomik açıdan homojen bir biçimde oluşturulmalı; katılımcıların araştrrma konusuna uygunluğu dikkatle analiz edilmelidir.

\subsection{Bulgular}

Araştırmada yer alan katılıcılar " $\mathrm{K}$ " şeklinde kodlanarak anonimleştirilmiştir ve K1'den başlayarak K7'ye doğru ilerleyen bir kodlama ile gösterilmektedir. Katılımcıların cinsiyet yoğunluğunun kadın olması özellikle belirlenen bir kriter değildir. Odak grup için davet edilen katılımcılardan kadın popülasyonu rastgele olarak yoğunluk göstermiştir. Katılımcıların demografik özellikleri şu şekildedir:

Tablo 2. Katılımcıların Demografik Bilgileri

\begin{tabular}{|c|c|c|c|}
\hline Katılımcı & Cinsiyet & Yaş & Eğitim Durumu \\
\hline K1 & Kadın & 36 & Lisans Mezunu \\
\hline K2 & Kadın & 36 & Lisans Mezunu \\
\hline K3 & Erkek & 46 & Yüksek Lisans Mezunu \\
\hline K4 & Erkek & 39 & Lisans Mezunu \\
\hline K5 & Kadın & 47 & Lisans Mezunu \\
\hline K6 & Kadın & 59 & Lisans Mezunu \\
\hline K7 & Kadın & 24 & Lisans Mezunu \\
\hline
\end{tabular}

Diğer yandan raslantısal örneklem yöntemiyle seçilen katılımcıların eğitim seviyelerinin lisans ve yüksek lisans olmasının ve görece yüksek sosyo-ekonomik seviyelere sahip olmalarının araştırma sonuçlarını etkilediği düşünülmektedir. Odak grup, homojen ve heterojen olmak üzere iki şeklide dizayn edilebilir. Heterojen gruplarda yer alan katılımcılar; grup içi tartışmaları tetikleyebileceği gibi grup içi çatışmaları kolaylaştırmayı ya da zorlaştırmayı da sağlayabilir. Homojen gruplarda yer alan katılımcılar ise belli başlı değişkenler açısından benzerlikler sağlanan sonuçlara ulaşılmasını sağlayabilir (Erdoğan ve Uyan- Semerci, 2021, s. 206). Tık odaklı haberciliğe dair düşünceleri ve tutumları anlamaya çalışırken orta üst sosyo-ekonomik seviye ve eğitim durumunun grup bazında farklı perspektiflerden 
yanıtlara ulaşılması ve alternatif yorumlarla karışılması bağlamlarında sınırlandırıcı bir etkiye sahip olduğu söylenebilir. Grubun ayrıştğı ve birleştiği konuların benzerlik göstermesi, ortak deneyimlerin tartışma gidişatını benzer görüşlere yönlendirmesi grup dinamiği içinde yer alan farklı bağlamları anlamak ya da tartışmaların nasıl geliştiğini gözlemlemek açısından sınırlı bir bilgi sunmaktadır. Toplumsal olarak inşa edilen olguların sosyal ortamlarda birey düşüncelerinin ya da yorumlarının nasıl belirlediğini anlamaya yönelik olarak yapılan odak grupta yer alan bu sınırlandırma daha sonraki çalışmalarda birden çok odak grup planlaması yapılarak ve bu grupların birbirlerinin düşüncelerine yönelik görüşleri karşılaştırılarak aşılabilir.

27.06.2021 tarihinde 7 kişinin katılımı ile online olarak gerçekleştirilen odak grup görüşmesinde katılımcılara aşağıda yer alan açık uçlu sorulardan oluşan bir akış yöneltilmiştir. Odak grup görüşmelerinde oluşturulan soru akışına cevap vermek istemeyen bir katılımc bulunmamaktadır. Bu sorular çerçevesinde katılımcılardan alınan cevaplar temalara ayrılmıştır.

1. Haber beklentinizi karşıladı mı, neden?

2. Başlıkla içerik uyumlu muydu?

3. Görsel kullanımı uygun muydu?

4. Haberin dili ve anlatımı nasıldı?

5. İnternette okuduğunuz haberlere güveniyor musunuz? Neden?

6. Bir haberi okumadan önce haber fotoğrafi ya da videosunun olması seçimlerinizde etkili oluyor mu?

7. Tık odaklı başlık/habercilik yaklaşımı medya kuruluşuna yönelik bakış açınızda farklılık yaratıyor mu? Haber içeriğine yönelik güveninizde azalma oluyor mu?

8. Okuduğunuz haberlerde tık odaklı başlıkları bilinçsizce tercih etmiş iseniz sonrasında ne yapıyorsunuz, haberi kapatiyor musunuz? Neden?

9. Bu tarz haberleri okuduktan sonra sizde hangi his/hisler uyandırıyor? Eğlence? Güvensizlik? Kandırılmışlık? Bir his uyandırmıyor?

Araştırmada yer alan katılımcıların odak grup çerçevesinde sorulara verdikleri cevaplar; internet haberciliğine güven-haber kaynağı ve haber tercihleri, haber dili ve anlatım, haberde görsel kullanımı, başlık-içerik uyumu ve tık odaklı başlıklara ve tık odaklı haberciliğe bakış olmak üzere beş tema üzerinden değerlendirilmektedir. Görüşmede haber seçiminde özgür bırakılan katılımcıların tık odaklı başlıklara yönelik refleksleri ve haber içeriklerine yönelik tepkileri gözlemlenmiştir. 
1., 2. 3. ve 4. sorular katılımcıların farkındalıklarını; 5. soru dijital haberciliğe olan güvenlerini, 6. soru haber seçimlerini etkileyen hususları, 7., 8. ve 9. sorular ise tepkilerini ölçmek üzere tasarlanmıştır.

\subsubsection{Internet Haberciliğine Güven, Haber Kaynağı ve Haber Tercihleri}

Katılımcıların ana akım medyaya ve ana akım haber sitelerine karşı bir güvensizlik geliştirdiğini söylemek mümkündür. Katılımcıların tümü haber takip etmeme sebeplerini taraflı habercilik anlayışı, yandaşlık kavramı, haberin doğruluğuna ve tarafsızlığına dair şüphelerle ilişkilendirirken birincil haber kaynağı olarak kullandıkları alternatif haber siteleri ve sosyal medyaya da değinmişlerdir.

İktidar yanlısı ya da muhalif olmaksızın bütün ana akım medya platformlarını "yandaş" ve taraflı bulduklarını belirtmişlerdir.

Katılımcıların tümü haberin, haber değerinden ziyade tıklanmaya odaklı hazırlandığını ve reklam odaklı olduğunu düşündüklerini de ifade etmiştir.

Bununla birlikte, $\mathrm{K} 1$ kodlu katılımcl, sosyal medyada kendi güven çemberini oluşturduğunu da ifade etmiştir. Bu çember sayesinde akış hâlinde olan haberler katılımcının yakın çevresinde yer alan ve güvenilir bulduğu kişilerin sosyal medyalarından takip edilmektedir. Bu güven çemberi bu isimlendirme ile K1 kodlu katılımcı tarafindan ifade edilmiş ancak diğer katılımcılar da benzer bir filtre tanımlaması yaptıklarını ifade etmişlerdir. Aynı zamanda katılımcıların tümü ana akım haber sitelerini sadece ileri bir araşttrma ve daha güvenilir kaynaklardan teyit amaçlı başlıkları belirlemek adına kullandıklarını, çoğunlukla doğruluğundan ve tarafsızlığından şüphe ettikleri haberleri çapraz kontrole tabi tuttuklarını ifade etmişlerdir.

Katılımcıların tümü siyaset ve gündem dışında kültür ve sanat haberlerine de ihtiyaç duyduklarını belirtmişlerdir.

Diğer taraftan araştırma sırasında 15 haberin bulunduğu havuzdan seçtikleri haberleri ise ilgi alanları ile ilişkilendirmişlerdir. Bu noktada katılımcıların ana akım medya ya da ana akım haber sitelerinde karşılaştkları haberleri tercih etme pratiklerinde Kalsson ve Strömback, çevrim içi haberleri karakterize ettiği iki özellikten biri olan etkileşim (Akt. Reis vd., 2015) özelliğinin etkili olduğunu söylemek mümkündür. Kalsson ve Strömback'e göre etkileşim, insanların yalnızca ilgilendikleri haberleri kullanma eğiliminde olmaları ile ilgiliydi. Araştırmaya katılan katılımcılarında haber seçim tercihlerinde kendileri ya da yakın çevrelerini ilgilendiren durumlara yönelik bilgi alma ihtiyacını karşılamaya çalıştıkları, her katıIımcının ortak dünya gündemini ilgilendiren haberler dışında kendi gündemlerini 
de ilgilendiren haberlere yöneldikleri tespit edilmiştir.

\subsubsection{Haber Dili ve Anlatımı}

Tablo 3. Katılımcıların Haber Dili ve Anlatımı Değerlendirmeleri

\begin{tabular}{|c|c|}
\hline K1 & $\begin{array}{l}\text { Çok uzatiyorlar. Çok ağdalı. Çok gereksiz uzathlıyor. Şu ana kadar bir tek haber por- } \\
\text { talı var. Kısa, öz. Onu takip ediyorum. Günlük olarak. Çok kısa, öz vermesi gereken } \\
\text { bilgiyi verip konuyu atlıyor. }\end{array}$ \\
\hline K2 & $\begin{array}{l}\text { Birbirini tekrar eden cümleler ve aslında bir noktaya varmayan uzun cümleler. Bir } \\
\text { cümlelik, hatta üç kelimeden oluşan bir cümlelik bilgiyi iki paragrafta bulamadı- } \\
\text { ğımız haberler oluyor. Mesela Rus deniz altısı ... Birbirini o kadar tekrar ediyor ki } \\
\text { aslında o kadar uzun bir haber olmasına gerek yok. }\end{array}$ \\
\hline K3 & $\begin{array}{l}\text { "Öğretmen haberinde. Oldukça uzunca bir şeyi okumanız gerekiyor, neye imza attı } \\
\text { ve neyi kaybetti diye. Haberin özü, başığın merak ettirdiği şeyi bulmanız için zaman } \\
\text { harcamanız gerekiyor. Kısaca taramayla bulmanız mümkün değil. Ayrıca mesleğin } \\
\text { belirtilmesi, cinsiyetin belirtilmesi haberde bir beklenti oluşturuyor. Öğretmen } \\
\text { olmasından dolayı bir şeye imza att ve her şeyini kaybetti gibi bir algı oluşturuyor. } \\
\text { Aslında ortada imza atılan bir şey de yok. Bir dolandırııılık haberi ve de çok bili- } \\
\text { nen bir dolandırıcılık yöntemi, yeni bir bilgi de değil. Dolayısıyla başlık, içerik olayın } \\
\text { gelişimi açısından ciddi bir kopukluk var. Başka bir şey buluyorsunuz, hayal kırıklığı } \\
\text { ama anlatım dili olarak fena değildi.” } \\
\text { "Ünlü şarkıcının sır ölümü haberi olan da oldukça haber başlı̆ından uzakt haber } \\
\text { dili olarak. Orada da klasik, son zamanlarda çok gördüğümüz, pandemi veya aşı } \\
\text { popülizmi kullanıımış. O bir firsat, her konu bir şekilde aşı ya da pandemi ile bağ- } \\
\text { lantılandırılırsa tıklanabileceği bilindiği gerçeği kullanmış. Orada da bir kötü niyet } \\
\text { görüyorum açıkçası ben. Ölen şarkıının ölüm sebebinin kovidle bağlantılı olup } \\
\text { olmadı̆̆ı da henüz bilinmiyor. Olma ihtimali var çünkü bir beyin kanaması ama } \\
\text { balkondan düşen kişi de } 10 \text { gün önce aşı olmuşsa aşı balkondan düşmeye sebep } \\
\text { oluyor gibi algı oluşturulmaya çalışılıyor. Trafik kazası yapmışsa ama bir gün önce } \\
\text { aşı olmuşsa aşı trafik kazasına mı sebep oluyor gibi saçma noktalara gelecek bir } \\
\text { korelasyon kurma çabası var. O anlamda anlatıma baktığımda çokça kovid bilgisi, } \\
\text { çokça İngiltere'de AstraZeneca aşısının nasıl algılandığına dair bilgi, çok azıcık, bir } \\
\text { yerde sadece şarkıcının ismi -çok da ünlü biri değil herhâlde- ölümünde sır olmadı- } \\
\text { ğı gerçeği üstüne üstlük var. Haber beklentiyi karşılamadı bende.” }\end{array}$ \\
\hline K4 & $\begin{array}{l}\text { Aşıyla ilgili olanı merak ettim sadece. Başlıktan ziyade, haberin içeriğindeki bilgiler. } \\
\text { O yazı bence yeterliydi. } \\
\text { Ben o şarkıcının ölümüyle ilgilenmedim. Tanıdığım bir isim de değil zaten. } \\
\text { Otizm teşhisi içeriği yeterli değil. } \\
\text { Öğretmene şok; haber niteliği taşımıyor, çok sıradan bir dolandırıcılık öyküsü. Yağ- } \\
\text { mur yağdı gibi bir haber olmuş. Çarpıtılmış buldum, diliyle ilgili bir değerlendirme } \\
\text { yapma gereği duymuyorum. }\end{array}$ \\
\hline K5 & $\begin{array}{l}\text { Birkaç haberi sonuna kadar okudum. Yalın ve sade bir dil vardı ama bilgilendirici } \\
\text { olması gereken haberlerde beni tatmin eden içerik bulamadım. }\end{array}$ \\
\hline K6 & $\begin{array}{l}\text { Dil çok da yanlış kullanılmamışt yazı metinlerinde imlaları çok da yanlış değildi } \\
\text { ama tekrarlar çok fazla olduğu için oldukça sıkıcı ve insanı okumaktan uzaklaştıran } \\
\text { bir etki yaratıyordu. }\end{array}$ \\
\hline
\end{tabular}




\begin{tabular}{|c|l|}
\hline K7 & $\begin{array}{l}\text { Haberin dili ve anlatımı fazlasıyla uzun geldi. Açıç̧ası haberler beklentimi pek } \\
\text { karşılamadı. Illk olarak başlık olarak merak uyandırdı fakat içeriğe gelince bekle- } \\
\text { diğimi bulamadım. }\end{array}$ \\
\hline
\end{tabular}

Katılımcılar, okudukları haberlerin uzun ve ağdalı olduğunu; gereksiz ayrıntılara boğulduğunu ifade etmiş, başlıkta ve/veya görselde söz verilen ya da ima edilen bilgiye ulaşamadıklarını söylemişlerdir. Kısa ve öz haberleri tercih ettiklerini, bunun zamandan tasarruf ettirdiğini düşündüklerini belirtmişlerdir. Haber takip etmeyi tercih eden katılımcılar, sadece gündemi görebilmek için "göz gezdirdiklerini" ama başlıklara güvenmedikleri için haberi tıklamayı tercih etmediklerini ifade etmiştir. Katılımcıların okudukları ya da göz gezdirdikleri haber inceleme pratikleri Chen ve arkadaşlarının (2015) tabloidleşme olgusu dâhilinde değerlendirilebilir. Katılımcılar, Chen ve arkadaşlarının (2015) belirttiği gibi dikkat çekici ve kendilerini o linke tıklamaya cesaretlendiren haberlere yönelmiş, ancak haberlerin tabloidleşme unsurlarının artması ile haberlerden uzaklaşmış ya da okuma pratiğini yarıda bırakmıştır.

\subsubsection{Haberde Görsel Kullanımı}

Tablo 4. Katılımcıların Haberde Görsel Kullanımı Değerlendirmeleri

\begin{tabular}{|c|c|}
\hline К1 & $\begin{array}{l}\text { "Haber başlığındaki görselden yola çıkarak tabi dikkatimi çekiyor, mesela en } \\
\text { uyumsuz olanı bilmem kimin şüpheli ölümü dediğinde kızcağızın orada masu- } \\
\text { mane bir fotoğrafi var, altını okuyorsun işte bir yerde alkollü bir mekânda sahte } \\
\text { içki almış. Demek istediğim, beni cezbeden görsel olmuyor hiçbir zaman. Hatta } \\
\text { görsel olmayan haberleri tercih ediyorum bu tip şeylerde." }\end{array}$ \\
\hline K2 & "Genel olarak görselle beslenmiyor haberler yani doğru görseller olmuyor." \\
\hline K3 & $\begin{array}{l}\text { "Keza çok gizli askeri sır haberinde de görsel itibariyle yanlış yönlendirmeydi. } \\
\text { Bile isteye İstanbul Boğazı'ndan bir fotoğraf koymuşlar ama haber İngiltere'de. } \\
\text { Askeri sırların bırakııdığı ile ilgili. Gemi de İngiliz değil Türk donanmasına ait bir } \\
\text { gönderme, o yüzden o da bir yanlış yönlendirme. } \\
\text { Basın dünyasının adaleti olsa ceza kesilmesi lazım o habere, şey gibi, yanlış ha- } \\
\text { ber yapıımış, görsel de yanlış gibi gözüküyor." }\end{array}$ \\
\hline K4 & $\begin{array}{l}\text { Birçoğu haberin başlığını, haberin içeriğini yansıtacak türden şeyler değildi. } \\
\text { Mesela İngiltere Savunma Bakanlığına ilişkin haber. Hangi ülkeye ait olduğu, ne } \\
\text { olduğu belli değil. Diğer haberlerde olan görseller yeterli değil. Bir tek ünlü şar- } \\
\text { kıcının ölümü. Onda da gerçekten o şarkıcıya ait mi kontrol etmedim. Uyumlu } \\
\text { ama nereye ait belli değil. }\end{array}$ \\
\hline K5 & $\% 80$ uyumluydu. \\
\hline K6 & Evet. Beş haberde de uyumlu. \\
\hline K7 & Görseller içeriğine göre pek uyumlu değildi. \\
\hline
\end{tabular}


Katılımcılar okudukları haberlerin görsellerini değerlendirirken haberin tercih etme aşamasında önemli bir etkiye sahip olduğunu belirtmiştir. 2 katılımcı dışındaki tüm katılımcılar haber havuzundan seçtikleri görsellerin haber içeriği ile ilişkisi olmadığını belirtmiştir. Katılımcılar ana akım medya ya da ana akım haber sitelerinde yer alan haber görselleri ve içerik arasındaki ilişkiyi gelen olarak değerlendirdiklerinde de çoğunlukla içerikten bağımsız görsel kullanımı ile karşılaştıklarını ifade etmiştir. Katılımcıların görsel ve içerik uyumuna dair yorumları da tabloidleşme kavramı çerçevesinde değerlendirilebilir. Tabloid formatı olarak isimlendirilebilecek olan bu formatların temel özelliği Olayların haberleştirilirken, okuyucunun ilgisini çekecek ve merak uyandıracak yönlerini öne çıkarmayı, "olayları" seyirlik bir öyküye, dönüştürmeyi ve genel olarak da gündelik hayatta gerçekleşen olayları kapsayan bu format (TESEV, 2012, s. 55), merak uyandırı$\mathrm{c}$ etkenler ile kullanılmaktadır. Okuyucunun dikkatini çekme amacı taşıyan bu haber formatında abartılı efektler, sürekli tekrar eden spotlar, sloganlaştırılmış açıklamalar, haberin klipleştirilen görüntüleri ya da foto galerileriyle okuyucunun dikkatinin sömürüldüğünü söylemek mümkündür. Katılımcılar da hem belirlenen haber havuzundan seçtikleri haberlerde yer alan görsellerinde hem de genel olarak okudukları haber görsellerinde bu merak uyandırıcı etkilerin kullanıldığını belirterek tabloidleşme formatının tik odaklı haber ve başlık tercihlerinde belirleyici bir etkiye sahip olduğunu vurgulamışlardır.

\subsubsection{Başlık ve İçerik Uyumu}

Tablo 5. Katılımcıların Başlık İçerik Uyumu Değerlendirmeleri

\begin{tabular}{|c|l|}
\hline K1 & $\begin{array}{l}\text { "Öyle bir başlık atyorlar ki sen sanki dünyanın en felaket şeyini okuyacakmışsın } \\
\text { ya da çok alakasız bir şey okuyacakmışsın gibi ama konu oradan bir şekilde bağ- } \\
\text { lanıyor fakat dikkat çekmek için bence çok abartlı başlıklar atlıyor." }\end{array}$ \\
\hline K2 & $\begin{array}{l}\text { "Hem abartılı hem bilgilendirici değil. Bazen öyle başlıklar oluyor içine girdiğiniz- } \\
\text { de iki cümle haber oluyor ve haber gelişmeler devam ediyor oluyor yani aslında } \\
\text { haber de olmuyor, sadece başlıktan ibaret oluyor haber." }\end{array}$ \\
\hline K3 & $\begin{array}{l}\text { "Bir kısmında tek tük uyumluluk vardı ama birçoğunda yanlış yönlendirme göre- } \\
\text { biliyordum." } \\
\text { "Biraz enayi gibi hissettim kendimi açıkçası. Oltaya gelmiş hissettim. Keza çok } \\
\text { gizli askeri sır haberinde de görsel itibariyle yanlış yönlendirmeydi. Bile isteye } \\
\text { İstanbul Boğazı'ndan bir fotoğraf koymuşlar ama haber İngiltere'de. Askeri sırla- } \\
\text { rın bırakılı̆ı̆ı ile ilgili. Gemi de İngiliz değil Türk donanmasına ait bir gönderme, } \\
\text { o yüzden o da bir yanlış yönlendirme. } \\
\text { Basın dünyasının adaleti olsa ceza kesilmesi lazım o habere, şey gibi, yanlış ha- } \\
\text { ber yapılmış, görsel de yanlış gibi gözüküyor." }\end{array}$ \\
\hline
\end{tabular}




\begin{tabular}{|c|c|}
\hline K4 & $\begin{array}{l}\text { "İçinde karşılaştı̆ım haberin detayları aslında çok klişeleşmiş bir dolandırıcılık } \\
\text { yöntemi olduğunu gördüm haberin içinde." } \\
\text { "Çok gizli sırlar otobüs durağında bulundu haberi: Görsel biraz yanıltıcıydı. Türki- } \\
\text { ye'den bir haber olabileceğini düşündüm, merak ettim. Ama yanlış yönlendiren } \\
\text { bir haberdi. Hangi ülkede, nerede gerçekleştiğine dair başlıkta belirten bir şey } \\
\text { olmadığından haberi okuduğumda, İngiltere'de, Ingiltere Savunma Bakanlığına } \\
\text { ait olduğunu öğreniyorum. Yani bu haberi, bu anlamda çok beğenmedim, hiç de } \\
\text { öyle sır falan vermiyor. Benim beklediğim anlamda diyeyim." } \\
\text { "Çok çarpıcı bir başlıkt, ilgimi çekti ister istemez. Haber beklediğim anlamda } \\
\text { açıklayıcı değildi. Net bir bilgi yok. Otizm illa çocuk yaşta mı yoksa böyle ilerle- } \\
\text { yen yaşlarda da olur mu diye net bir bilgi yok aslında. Sansasyonel bir başlığı } \\
\text { olduğu için çekiyor ister istemez." } \\
\text { "Ünlü şarkıcının sır ölümü diye bir başlık vardı. Bu da yine başlık yanıltıcı, yön- } \\
\text { lendirici bir başlık. İki hafta önce aşı olmuştu diye bir alt başlık vardı. Hâliyle } \\
\text { yine daha önce dediğim gibi vakalarla ilgili haber olduğu gibi bu da aşıyla ilgili } \\
\text { olduğundan dolayı onu da merak ettim okudum. Hatta bunu açınca aslında daha } \\
\text { ilgi çekici tarafi bence haberin içeriğinde saklıydı. Başlığa almadıkları bu AstraZe- } \\
\text { neca İngiltere'de kullanılan aşıyla ilgili detaylar vardı. Onu mesela merak ettim. } \\
\text { Bu aşının bu tarz ölüme sebep olan yan etkileri varmış.” }\end{array}$ \\
\hline K5 & $\begin{array}{l}\text { Yarı yarıya uyumlu. Yüzeysel haberler, dikkat çeken başlıklar seçilmiş haberin } \\
\text { okunması ile ilgili. Ama bazı haberlerde başlık bile haberin sonuna kadar okuma- } \\
\text { ma yetmedi. }\end{array}$ \\
\hline K6 & $\begin{array}{l}\text { Uyumluydu aslında ama içerikler ne kadar kıymetli o tartşılabilir. Başıklar ve } \\
\text { görseller de sakınca yoktu ama içerikler ne kadar doyurucuydu o ayrı bir mevzu. }\end{array}$ \\
\hline K7 & Başıklar içeriğine göre asparagas haber olarak yansıdı. \\
\hline
\end{tabular}

Katılımcılar, okudukları haberlerin başlıklarını; asparagas, yüzeysel ya da abartılı olarak ifade etmiş, başlıkta söz edilen ya da ima edilen bilgiye ulaşamadıklarını, haber içeriğinde klişeleşen olayların yer aldığını söylemişlerdir. Katılımcıların başlık ve içerik uyumuna dair yorumları sansasyonelleştirme kavramı çerçevesinde değerlendirilebilir. Çelik'e göre tabloid haber format ve sansasyonel haber formatı arasında fark bulunmaktadır. Sansasyonel format, "sansasyonel bir olayı yakalamak veya sıradan bir olayı sansasyonelleştirmek" üzerinden gerçekleşmektedir. Bu format sadece okuyucunun merak duygusunu harekete geçirmenin yanı sıra daha fazla gazetecilik pratiğinin de uygulanmasını içermektedir. Çelik'e göre tık odaklı habercilikte ele alınacak olan konu, önemli veya güncel olsun ya da olmasın, sansasyonel formatın biçimsel özellikleri kullanılarak günün en çok okunan haberi hâline dönüştürülebilir (Çelik, 2020, s. 17). Katılımcılar hem belirlenen haber havuzundan seçtikleri haberlerde yer alan başlık-içerik uyumu değerlendirmelerinde hem de genel olarak okudukları/tükettikleri haberlerde yer alan başıı-içerik uyumu değerlendirmelerinde sansasyonel formatın kullanımının öne 
çıktığına yönelik açıklamalarda bulunarak başlıklar ile haber içerikleri arasındaki uyumun beklentilerini karşılamadığını ifade etmiştir. Bu noktada katılımcıların değerlendirmeleri ışığında haberlerde kullanılan başlık-içerik arasındaki ilişkinin thk yemi çerçevesinde oluşturulduğunu söylemek mümkündür. Zhou, ttk yemini üç başlık altında değerlendirmektedir (akt. Kalender, 2019, s. 10). İlk olarak tık yemi, kullanıcıların vaktini boşa harcamasına neden olmaktadır. 2 katılımcı dışındaki tüm katılımcılar haberde beklentilerinin karşılanmadığını ve boşa zaman harcadıklarını ya da bildikleri bir olayın haber metni ile doyurucu bir bilgiye ulaşamadıklarını belirtmiştir. İkinci olarak tık yemi, gazetecilik mesleğinin itibarının zedelenmesine ve haber kuruluşuna duyulan güvenin azalmasına neden olmaktadır. Katılımcılar sıklıkla karşılaştıkları "tık yemi" habercilik formatı sonrasında haber kaynaklarına olan güvenlerini kaybettiklerini, ana akım medyayı tüketmeyi tercih etmediklerini, alternatif medya araçlarına yönelmek zorunda kaldıklarını vurgulamışlardır. Üçüncü olarak ise tık yemi, habercilikle bağdaşmayan kalitesiz içeriklerin yaygınlaşmasına neden olmaktadır. Katılımcılar özellikle tabloid ve sansasyonel haber formatlarına dair açıklamaları ile kalitesiz haber içeriklerine dair görüşlerini belirtmişlerdir.

\subsubsection{Katılımcıların Tık Odaklı Başlıklara ve Tık Odaklı Haberciliğe Bakışı}

Araştırma sonuçları, katılımcıların tamamının tık odaklı başlıkların farkında olduğunu göstermektedir. Reklama ve ticari kazanca yönelik olarak değerlendirdikleri bu habercilik anlayışı nedeniyle ana akım haber sitelerinden uzaklaştıklarını; alternatif haber sitelerine ve sosyal medya platformlarına yöneldiklerini ifade etmişlerdir. Bununla birlikte, katılımcılar araştırma çerçevesinde belirlenen haber seçimlerini, belirli beklentilerle gerçekleştirmiştir. Haberin başlığında veya görselinde ön plana çıkan merak unsurunun seçimlerinde etkili olduğunu söylemek mümkündür. Ancak haber okuma deneyimi sonunda beklentilerinin karşılanmadığını gerekçeleriyle birlikte açıklamışlardır. Diğer yandan, katılımcıların beklentilerinin karşılanmayacağının bilinciyle bu tarz haberlerin yoğun olduğunu düşündükleri ana akım haber sitelerinden kaçındıkları da söylenebilir.

\section{Sonuç}

WEB 2.0 teknolojisi ile sosyal medyanın ve internetin günümüzde gündelik yaşam pratikleri içinde önemli bir yere sahip olması, bilgi edinme, enformasyon akışı sağlama ve enformasyonu depolama alışkanlıklarında dönüşümlere neden olmuştur. Bu dönüşümlerin gerçekleşmesinde geleneksel medyadan farklı temel unsurlara sahip olan yenimedya araçlarının hipermetinsellik, çoklu ortam, güncellenebiliriçerik, yalan haber, tık odaklı habercilik anlayışı, abartılı başlık, görsel ve içerik kullanımı 
gibi etkenleri habercilik etiğine dair sorunlu alanların oluşmasına neden olmaktadır.

Dijital ve mobil dünyada üretilen habercilik anlayışına dair kullanıcı reflekslerinin değerlendirilmesini içeren bu araştırmanın da merkezinde haber içeriklerine yönelik geliştirilen güvensizlik duygusunun olduğunu söylemek mümkündür.

Kullanıcıların haberciliğe ilişkin geliştirdikleri güvensizliğinin altında birçok farklı etken -ekonomik, politik, sosyolojik ve psikolojik- bulunmaktadır. Bu çalışma, habere olan güvensizliğin altındaki nedenlerden sadece biri olarak kabul ettiğimiz tık odaklı başlıklara, tık odaklı habercilik anlayışına ve söz konusu kavramların haberin unsurlarında yarattğı/yaratabileceği/yaratması gereken değişikliklere odaklanmaktadır. Dijitalleşme ve özellikle sosyal medyanın aktif kullanımı ile bilgi akışında sınırsız rekabetle karşılaşan meslek mensuplarının geleneksel rating/ tiraj kaygısı, yerini “tık" ve "sayfa görüntülenme" kaygısına bırakmış görünmektedir. Bu noktada, tık odaklı başlıklar ve tık odaklı habercilik özünde haberi ilk okuyucuya ulaştırma refleksi ve ticari kaygı taşıyan bir habercilik anlayışı karşımıza çıkmaktadır. Söz konusu anlayışta, haberin ve haberciliğin kamusal yararı büyük ölçüde göz ardı edilmektedir. Bilgiye ulaşma hızının merkeze alındığı bu bakış açısı ticari kaygılar ile birleştirildiğinde enformasyonun bulanıklaştiğı ve bilginin etkisizleştiği bir zeminin yaratılmasına neden olduğu görülmektedir. Diğer yandan teknolojik gelişmelerin, değişen çevre ve toplum yapısının haberciliğin özünde ve unsurlarında bazı değişiklikler gerektirmesi beklenen bir durumdur. Ancak tık odaklı haber üretimini açıklamak için ifade edilen toplumun nabzını tutma isteği ve hızlılık gibi nedenler habercilik anlayışındaki değişimi yorumlamak için yeterli değildir.

Tık odaklı habercilik anlayışını yorumlamak ve okuyucu reflekslerini değerlendirmek amacıyla yapılan odak grup görüşmesi, 27.06.2021 tarihinde 7 kişinin katılımı ile online olarak gerçekleştirilmiştir. İki aşamalı gerçekleştirilen görüşmede öncelikle katılımcılara açık uçlu sorulardan oluşan bir akış yöneltilmiştir. Bu sorular çerçevesinde katılımcılardan alınan cevaplar; internet haberciliğine güven-haber kaynağı ve haber tercihleri, haber dili ve anlatımı, haberde görsel kullanımı, başlık-içerik uyumu, tık odaklı başlıklara ve tık odaklı haberciliğe bakış olmak üzere beş tema üzerinden değerlendirilmiştir.

Araştırmada, rastlantısal örneklem yöntemiyle seçilen katılımcıların eğitim seviyelerinin lisans ve yüksek lisans olmasının ve görece yüksek sosyo-ekonomik bir seviyelere sahip olmalarının sonuçları etkilediği düşünülmektedir. Kathlımcıların tamamının ana akım medyaya ve ana akım haber sitelerine karşı bir güvensizlik 
geliştirdiğini söylemek mümkündür. Bir diğer deyişle tık odaklı başlıklara yönelik tasarlanan araştirma, odak grubun dinamikleri içerisinde habere ve haberciliğe olan güvenin sorgulandığı ve tartışıldığı bir boyuta taşınmıştır. Bu haber sitelerinde oluşturulan haber çerçevelerinin konuyla ilgili belirli gruplara/kişilere ait görüşler dâhilinde oluşturulduğu; haberde farklı görüşlere yer veren bir dengelenme yapısının kurulmadığını belirtilmektedir. Katılımcılar ana akım medyada haberin, haber değerinden ziyade tıklanmaya odaklı hazırlandığını ve reklam odaklı olduğunu düşündüklerini ifade etmişlerdir. Birincil haber kaynağı tercihlerini ise alternatif haber siteleri ve kendi tercihleri çerçevesinde oluşturdukları sosyal medyaları oluşturmaktadır. Bu noktada K1'in kullandığı "güven çemberi" kavramı dikkat çekicidir. Katılımcılar, başlıkları seçerken merak unsuruna ve kendilerini ve/veya yakın çevrelerini ilgilendiren konulara odaklanmışlardır.

Katılımcılar, okudukları haberleri, "uzun ve ağdalı", gereksiz bilgiler içeren, kendini tekrar eden ve başlıkta karşılaştıkları sorunun cevabını kısaca vermeyen, beklentilerini karşılamayan haberler olarak nitelemişlerdir. Bu bağlamda tk odaklı habercilik anlayışında haber dilinin hikâyeleştirildiği, objektif ve tarafsız bir kullanımından uzak inşa edildiğini belirtilmektedir. Katılımcılar, ana akım haber sitelerinde yer alan haber görselleri ve içerik arasındaki ilişkiyi genel olarak değerlendirdiklerinde çoğunlukla içerikten bağımsız görsel kullanımı ile karşılaştıklarını ifade etmişlerdir. Ancak görsel kullanımının da haberin belirlenmesinde etkili olduğunun altını çizmişlerdir. Bu noktada tık odaklı habercilikte görsel kullanımını haber içeriğinden bağımsız, anonim bir görsel ya da temsili imaj kullanımı ile sunulduğu, bu olaydan bağımsız görsel ve imaj kullanımında duygusal olarak sömürüyü güçlendirecek ya da olayın etki gücünü arttracak niteliğe sahip görsellerden oluştuğu belirtilmektedir. Buradan katılımcıların haber üretiminde remiks ya da kullanışlı karışım (mash-up) tekniği ile yapılan enformasyonlara ilgi duydukları sonucunu çıkarmak mümkündür. Araştırma sonuçlarına göre katılımcılar tık odaklı başlıkların ve tık odaklı haberciliğin farkındadır. Yanıltıcı başlık ve görsel kullanımı, gereksiz tekrarlar, uzun ve ağdalı bir dil, başlığın ve içeriğin uyumsuz olması gibi sorunları habere ulaştıktan kısa bir süre sonra dile getirmektedirler. Araştırma sonuçlarını Zhou'nun üç başlık altında değerlendirdiği tık yemi kavramsallaştırması üzerinden değerlendirmek de mümkündür (akt. Kalender, 2019, s. 10). İlk olarak tık yemi, kullanıcıların vaktini boşa harcamasına neden olmaktadır. Nitekim 2 katılımcı dışındaki tüm katılımcılar haberde beklentilerinin karşılanmadığını ve boşa zaman harcadıklarını ya da bildikleri bir olayın haber metni ile doyurucu bir bilgiye ulaşamadıklarını belirtmiştir. 
İkinci olarak tık yemi, gazetecilik mesleğinin itibarının zedelenmesine ve haber kuruluşuna duyulan güvenin azalmasına neden olmaktadır. Katılımcılar özellikle ana akım haber kaynaklarına olan güvenlerini kaybettiklerini, haber ihtiyaçlarını alternatif haber sitelerinden ve sosyal medya platformlarında oluşturdukları "güven çemberi"nden karşıladıklarını ifade etmişlerdir. Son olarak tık yemi, habercilikle bağdaşmayan kalitesiz içeriklerin yaygınlaşmasına neden olmaktadır. Katılımcılar da özellikle tabloid ve sansasyonel haber formatlarına dair açıklamaları ile kalitesiz haber içeriklerine dair görüşlerini belirtmişlerdir. Bir başka deyişle yanıltıcı görsel ve başlıklarla oluşturulan tık yemleri, kısa vadede kullanıcıyı habere çekmeyi başarsa da uzun vadede habere ve haberciliğe karşı bir güvensizlik dalgası oluşturmakta ve alternatif haber kaynağı arayışına itmektedir. Günümüz şartlarında dinamik, sürekli değişen çevre, haber ihtiyacını her geçen gün arttırmaktadır. Bu noktada, kullanıcıların beklentileri doğrultusunda kısa ve öz haberler içeren, başlık-içerik uyumu dikkate alınmış, farklı gündemleri bir arada barındıran, tarafsız bir haber yaklaşımına, "güven uyandıracak" bir habercilik anlayışına ve güncel enformasyon akışı sağlayacak haber sitelerine ihtiyaç vardır.

\section{Çıkar Çatışması Beyanı}

Makale yazarları herhangi bir çıkar çatışması olmadığını beyan etmiştir.

\section{Araştırmacıların Katkı Oranı Beyan Özeti}

Yazarlar makaleye \%50 (1. Yazar), \%50 (2. Yazar) oranında katkı sağlamış olduklarını beyan ederler.

\section{Kaynakça}

Bek, M. G. (2004). Research Note: Tabloidization of News Media: An Analysis of Television News in Turkey [Araştırma Notu: Haber Medyasının Tabloidleşmesi: Türkiye'de Televizyon Haberleri Üzerine Bir Analiz]. European Journal of Communication, 19 (3), 371-387.

Beleslin, I.; Njegovan, B. R.; Vukadinovic, M. S. (2017). Clickbait titles: Risky formula for attracting readers and advertiser. XVII International Scientific Conference o Industrial Systems (IS'17) Novi Sad, Serbia, October 4- 6, 364-369.

Berger, J. (2014). Readers Don't Like to Be Fooled, Retrieved from https://www.nytimes. com/roomfordebate/2014/11/24/you-wont-believe-what-these-people-say- 
about-click-bait/readers-dont-like-to-be-fooled, 26.06.2020.

Blom, J. N.; Hansen, K. R. (2015). Click Bait: Forward-Reference as Lure in Online News. Journal of Pragmatics, 76, 87-100.

Chakraborty, A., Paranjape, B., Kakarla S. and Ganguly, N. (2016). Stop Clickbait: Detecting and preventing clickbaits in online news media, 2016 IEEE/ACM International Conference on Advances in Social Networks Analysis and Mining (ASONAM), 9-16.

Chen, Y., Conroy, N. J., and Rubin, V. L. (2015). Misleading Online Content. Proceedings of the 2015 ACM on Workshop on Multimodal Deception Detection, WMDD'15.

Çaplı, B. (2002). Medya ve Etik. Ankara: İmge Kitabevi.

Çelik, R. (2020). Tık Odaklı Habercilikte "Tık Yemi" Taktiği: Koronavirüs (Kovid-19) Örneği. Social Sciences Research Journal, 9 (2), 14-25.

Dönmez, İ. H. (2010). İnternet Haberciliğinde Tıklanma Kaygısı ve 'Kapan' Manşetler. Akdeniz Üniversitesi İletişim Fakültesi Dergisi. Sayı: 14, 105-129.

Erdoğan E. Uyan Semerci P. (2021). Toplumsal Araştırma Yöntemleri İçin Bir Rehber: Gereklilikler, Sınırlılıklar ve İncelikler. İstanbul: Bilgi Üniversitesi Yayınları.

García O, B., Gallur S., S., López García, X. (2017). "Use of clickbait in the online news media of the 28 EU member countries". Revista Latina de Comunicación Social, $72,1.261-1.277$.

Ince, M. (2018). İnternet Haberciliğinde Çok Tıklanma Beklentisi ve Tuzak Başlıklar. Karabük Üniversitesi Sosyal Bilimler Enstitüsü Dergisi, 2018, 8 (2), 297-313.

Kalender, A. B. (2019). İnternet Haberciliğinde Clickbait Savaşları: Bir Okuyucu Tepkisi Olarak Limon Haber Örneği. Dördüncü Kuvvet. 2 (2), 1-21.

Karaca, A. (2019). News Readers' Perception of Clickbait News. Master's of New Media Thesis, Kadir Has University School of Graduate Studies Department of Communication Studies, İstanbul.

Korap Özel, E.; Deniz, Ş. (2019). "Tık” ve "Etik” Arasında Sıkışan Gazetecilik Erciyes İletişim Dergisi | Ocak/January, 6, 1, 443-466.

Lee, A. M., Lewis, S. C. and Powers, M. (2014). Audience Clicks and News Placement: A Study of Time-Lagged Influence in Online Journalism, Communication Research, 41(4), 505-530.

Max Plank Society (2016). Academic journal articles with 'clickbait-y' characteristics are shared more widely. 17.08.2016. Retrieved from https://phys.org/ news/2016-08-academic-journal-articles-clickbait-y-characteristics.html, (Erişim Tarihi: 26.06.2020). 
McDonnell, J. (2016). Quality Journalism vs. The Clickbait Culture, The Odyssey Online. Retrieved from https://www.theodysseyonline.com/quality-journalism-clickbait-culture, (Erişim Tarihi: 13.06.2020).

Özyal, B. (2016). “Tık Odaklı Habercilik: Tık Odaklı Haberciliğin Türk Dijital Gazetelerindeki Kullanım Biçimleri", Global Media Journal TR Edition, 6 (12), 273-301.

Reis, J.; Benevenoto, F.; Vaz de Melo Pedro O. S.; Prates, R.; Kwak, H.; An, J. (2015). Breaking the News: First Impressions Matter on Online News, Retrieved from https://arxiv.org/pdf/1503.07921v2.pdf, (Erişim Tarihi: 29.06.2020).

Reuters Digital Report 2020.

TESEV (2012). İktidarın Çarkında Medya: Türkiye'de Medya Bağımsızığı ve Özgürlüğü Önündeki Siyasal, Yasal ve Ekonomik Engeller. İstanbul: İmak. 


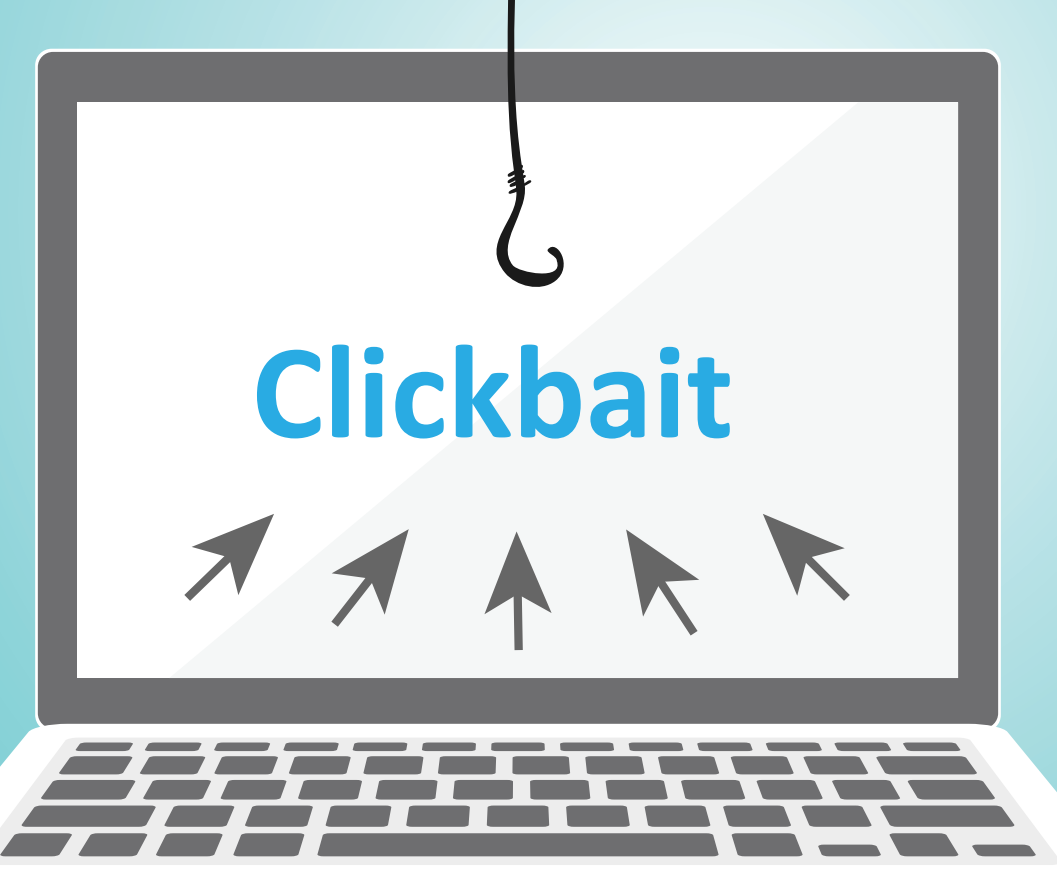

